\title{
Research on Development Potential and Comprehensive Utilization of Crop Straw Resources in Jilin Province
}

\author{
Xi Weidong ${ }^{1, a}$, Yu Guanfang ${ }^{1, b}$ and Sun Yutao ${ }^{1, c}$ \\ ${ }^{1}$ School of Economics and Management, Northeast DianLi University, JiLin, China \\ a407210031@qq.com, byuguanfang123@126.com, c 811855098@qq.com
}

Keywords: Development potential; Comprehensive Utilization; Effect.

Abstract. Jilin Province has inherent advantages in straw resources. Analysis of development potential a can help to realize the current situation of resource exploitation. The paper analyzes the development potential of the crop straw in Jilin Province. And then, it studies the direct economic effect and environmental effect of recently crops straw comprehensive development, according to the types of crops straw comprehensive utilization.

\section{The Potential of Crop Straw Development in Jilin Province}

Straw Distribution. Jilin Province with a total of 49 counties (cities), but affected by geography, climate and other factors, crop yields have obvious regional distribution, In the middle of Jilin province, Fuyu Nongan, Dehui, Lishu, Qianguo, Changling, Yitong, Zhenlai and other eight counties grain production were more than one million tons, with its output accounting for 58.36 percent of the province's total grain output. And have 14 counties which grain output below 50 million tons ${ }^{[1]}$, but its production accounts for only $4.65 \%$ of the province. Therefore, Jilin Province straw yield also has obvious regional distribution with the influence of the grain crops distribution. Apparently, the central region is the main producing areas of straw, the eastern region of straw yield is smaller.

The Development Potential of Crop Straw. By referring to the "Statistical Yearbook of Jilin Province " (2005-2014), we get the output of the main crops. In Jilin Province, soybean production is higher than others in the beans crops, so it is listed separately, and other beans crops were classified into "Other Beans". Sesame, sunflower, cottonseed, castor and other oil crops yield were classified into "Other oil crops" because their lower production. The main crop yields in Jilin province can be seen in Table1:

Table1 2004-2013 Crop yields production in Jilin Province

\begin{tabular}{lllllllllll}
\hline Type & 2004 & 2005 & 2006 & 2007 & 2008 & 2009 & 2010 & 2011 & 2012 & 2013 \\
\hline Rice & 437.62 & 478 & 493 & 500 & 579 & 505 & 568.5 & 623.5 & 532.03 & 563.27 \\
Wheat & 3.37 & 2.68 & 3 & 2 & 3.22 & 1 & 1.24 & 1.3 & & \\
Corn & 1810 & 1815 & 1984 & 1800 & 2083 & 1810 & 2004 & 2339 & 2578.8 & 2775.7 \\
Sorghum & 28.07 & 65.99 & 42 & 31 & 33.13 & 25 & 66.82 & 37.9 & 82.81 & 85.43 \\
Soybean & 152.06 & 152.83 & 121 & 78 & 101.35 & 82 & 86.57 & 78.79 & 40.83 & 45.39 \\
Other Beans & 14.85 & 22.63 & 29 & 14 & 9.83 & 3 & 26.33 & 22.47 & 11.74 & 13.39 \\
Other cereals & 6.3 & 9.81 & 9 & 4 & 0.47 & 7 & 13.55 & 13.54 & 28.11 & 19.36 \\
Sunflower & 9.38 & 16.19 & 18.66 & 11.32 & 17.17 & 17.24 & 29.1 & 31.1 & 29.69 & 25.78 \\
Other oil & 28.72 & 38.26 & 39.71 & 32.39 & 34.67 & 33.16 & 41.34 & 38.46 & 51.03 & 58.23 \\
crops & 0.3 & 0.61 & 0.12 & 0.05 & 0.25 & 0.05 & 0.02 & 0.02 & 0.01 & \\
Bast & 0.3 .03 & \\
Tobacco leaf & 5.4 & 5.97 & 7.04 & 6.13 & 6.53 & 6.65 & 7.23 & 7.23 & 8.13 & 6.06 \\
\hline
\end{tabular}

The production of main crops have list in Table1, and we can use Grass Valley ratio to get the annual straw yield. And according to existing research, the Grass Valley ratio will change with the influence of year Growth and technological conditions and other factors. Herein by reference 
literature, Jilin province has the similar conditions for agricultural production with Heilongjiang Province and Liaoning Province. Using existing data and combined with the national average Grass Valley ratio as basics, we will get Grass Valley ratio of different crops in JiLin Province as Table2:

Table2 Grass Valley ratio of different crops

\begin{tabular}{ccccccc}
\hline Crops & Rice & Wheat & Corn & Sorghum & Soybeans & $\begin{array}{c}\text { Other } \\
\text { soybeans }\end{array}$ \\
\hline Grass Valley Ratio & 1 & 1.1 & 2 & 2 & 1.7 & 1.7 \\
\hline Crops & $\begin{array}{c}\text { Other } \\
\text { cereals }\end{array}$ & $\begin{array}{c}\text { Sunflower } \\
\text { seeds }\end{array}$ & $\begin{array}{c}\text { Other oil } \\
\text { crops }\end{array}$ & Beast & Tobacco leaf \\
\hline Grass Valley Ratio & 1.7 & 2 & 2.63 & 6.65 & 0.66 \\
\hline
\end{tabular}

Biomass resource potential crop yields can be expressed as the product of the ratio and different crops production. And annual amount of biomass resources can be represented by a year of major crop yields compared with grass valley ratio of different crops (Table2) .Then we can get the production of Jilin Province from the year of 2004 to 2013, and we can get the Table3.

Table3 Potential of biomass resources in Jilin Province (2004-2013)

\begin{tabular}{lllllllllll}
\hline Year & 2004 & 2005 & 2006 & 2007 & 2008 & 2009 & 2010 & 2011 & 2012 & 2013 \\
\hline Resources & 4515 & 4704 & 4971 & 4442 & 5136 & 4463 & 5106 & 5750 & 6208 & 6639 \\
\hline
\end{tabular}

According to the amount of potential resource data in Table3, we can draw a scatter plot. We can get the information that the amount of crops straw resources in Jilin Province is changed stably, the overall trend shows a slow rise.

Comprehensive Utilization Rate of Straw in Jilin Province. The results can be obtained from the above that the amount of biomass resources in Jilin Province is relatively stable. But it can't explain all. Then we access to relevant papers, and collect comprehensive utilization of straw in JiLin Province from the year of 2008 to 2014, just as follows in Table4:

Table 4 Comprehensive utilization rate of straw in Jilin province (2008-2014)

\begin{tabular}{llllllll}
\hline Year & 2008 & 2009 & 2010 & 2011 & 2012 & 2013 & 2014 \\
\hline Rate & $15 \%$ & $13 \%$ & $15 \%$ & $20 \%$ & $20 \%$ & $35 \%$ & $43.5 \%$ \\
\hline
\end{tabular}

It can be seen the data from Table4, Jilin Biomass resource utilization has improved from the year of 2008, but is still in a relatively low status. In the year of 2013, Jilin straw utilization rate just has $35 \%$, of which straw feed only account for $15.5 \%$, and about two-thirds of straw resources is used as a fuel or rural life in the field of waste incineration. In the year of 2014, there are about 39.6 million tons of straw resources can be use, the direct application of rural life accounted for $40 \%$, the combustion exhaust gas account for more than $25 \%$. While the utilization of directly used in the development and utilization below 43.5\%.

According to " National Development and Reform Commission of 2014", Ministry of Agriculture jointly issued "Straw Utilization Technology Catalog (2014)", in order to access the task of "increase the straw comprehensive utilization rate to more than $80 \%$ in the year of 2015 ", and guiding the country to promote the practical utilization of straw mature technology and promote straw comprehensive utilization of industrial development. Then we can see that the biomass utilization rate in Jilin province is less than $43.5 \%$ now, there is considerable room for development compared with the goal of more than $80 \%$.

According to the above analysis, it can be concluded: From a practical analysis, the potential of crops straw development is huge in Jilin province, there is an important value for biomass resources development. 


\section{Direction and Effects of Crops Straw Comprehensive Utilization}

The straw comprehensive utilization way is divided into four kinds: "Straw"(only use straw)," Straw + Other waste "(combine the straw and other waste)," Straw curing "," Straw gasification ".

There are two effects of crops straw comprehensive utilization, including economic effects and environmental effects. In terms of economic effects, it includes power generation, heating, green energy (biogas and briquetting), organic fertilizer, farmers comprehensive income, as shown in Table 5. In terms of environmental effects, it includes $\mathrm{CO}_{2}$ emissions, $\mathrm{COD}$ reduction and PM reduction just shown in Table 6.

Table5 Straw using types and economic efficiency

\begin{tabular}{|c|c|c|c|c|c|c|c|}
\hline Type & Direction & $\begin{array}{l}\text { Utilization } \\
/ 10^{4} \mathrm{t}\end{array}$ & $\begin{array}{l}\text { Electrical } \\
/ 10^{8} \mathrm{kwh}\end{array}$ & $\begin{array}{l}\text { Heat } \\
/ 10^{4} \mathrm{GJ}\end{array}$ & $\begin{array}{l}\text { Solid } \\
/ 10^{4} \mathrm{t}\end{array}$ & $\begin{array}{l}\text { Income } \\
/ 10^{8}\end{array}$ & $\begin{array}{l}\text { Standard } \\
\text { coal } / 10^{8} \mathrm{t}\end{array}$ \\
\hline \multirow{4}{*}{$\begin{array}{l}\text { Straw and } \\
\text { Other waste }\end{array}$} & $\begin{array}{c}\text { Straw }{ }^{[3]} \\
\text { "Straw + Other }\end{array}$ & 600 & 49.5 & 1800 & 17.2 & 16.8 & 165.6 \\
\hline & waste" & 300 & 24.8 & 900 & 8.6 & 8.4 & 82.8 \\
\hline & $\begin{array}{c}\text { Straw curing } \\
\text { Straw }\end{array}$ & 100 & - & - & - & 6.5 & 46.7 \\
\hline & gasification & 45.6 & - & - & - & 3.6 & 21.3 \\
\hline
\end{tabular}

Table6 Utilization direction and environmental benefit

\begin{tabular}{ccccc}
\hline Type & Utilization direction & $\mathrm{CO}_{2} / 10^{4} \mathrm{t}$ & $\mathrm{COD} / 10^{4} \mathrm{t}$ & $\mathrm{PM} / 10^{4} \mathrm{t}$ \\
\hline Straw and Other waste & Straw & 643.6 & - & 210.2 \\
& "Straw + Other waste" & 321.8 & - & 11.3 \\
& Straw curing & 114.7 & - & 39 \\
& Gasification station & 52.6 & - & 17.8 \\
\hline
\end{tabular}

\section{Effect Analysis}

Economic Effects. The direct and indirect economic effect is very obvious: Firstly, the straw ash can become excellent fertilizer by simple processing, either replace imported high prices potash, but also can improve soil quality; Secondly, preparing the remaining biogas and biogas slurry is an excellent organic fertilizer (substitute phosphate and nitrogen), not only can reduce crop pests and diseases, and also can increase crop (and fisheries) production, while reducing the amount of the purchase amount and application of fertilizers and pesticides, thus reducing farmers' production expenses; and last, generating heat can be used to heat the fruit and vegetable in greenhouses and livestock pens from autumn to spring for three quarters, which can reduce the cost of planting and breeding and increase the farmer-season revenue.

Environmental Effects. The utilization of straw can reduce 2.2 million tons of particulate matter emissions from the burning of straw. As the development and utilization of straw, cause nearly 400 million tons of $\mathrm{CO}_{2}$ emission reduction, 980,000 tons of COD emissions and more than 220 tons of particulate matter reduction.

Removing the direct environmental effects, the utilization of straw can make a big difference in rural environment: Firstly, reducing the heavy metal contamination of soil and water pollution and improve the quality of crops; secondly, it help to improve the air quality in rural areas and reducing the chance of respiratory infections villagers during fall and winter, thus reducing medical expenses.

\section{Conclusions}

Biomass resources in Jilin province have unique advantage, the utilization of straw resources can promote the utilization of other resources. The utilization of crops straw in Jilin province has a significant effect. And At the micro level, the first level is to increase farmers' revenue. And the second level is to increase economic efficiency of power generation companies. At the macro level, 
firstly, improving the quality of rural environment and increase the quality and safety of agricultural products by reducing $\mathrm{CO}_{2}$, particulate matter, $\mathrm{COD}$ emissions; the second is increase a significant number of jobs; Third, it help to promote the process of urbanization county.

\section{References}

[1] Statistical Yearbook of Jilin Province (2003-2014)

[2] Chao Yang. Why straw power plant lack of raw materials. Chinese Economic Herald 2012. In Chinese

[3] Xifeng Zhu, Xiaoping Yuan. The Analysis of Straw Gasification. Rural Energy (Agriculture Press, BeiJing, 2002), p. 28-29. In Chinese

[4] Yanfei Li. Engineering and Technology Exploration and Research on Agriculture Engineering Technology (Agricultural Engineering and Technology Press, BeiJing, 2012), p.22-25 In Chinese

[5] Karekezi S, Ranja T. Renewable energy technologies in Africa. London: Zed Books; 1997.

[6] Shushen Wu, Meiying Tan, Wei Liu. Effect on cost control of biogas project for livestock and poultry manure pollution, in China Ecological Agriculture, (Science Press, BeiJing, 2012), p.247-252 .In Chinese

[7] Hughes EE, Tillman DA. Biomass co ring: status and prospects. Fuel Process Technology 1998; 54, p.127-42. 